\title{
Happiness and pro-environmental consumption behaviors
}

\author{
Hung Vu Nguyen, Mai Thi Thu Le and Chuong Hong Pham \\ National Economics University, Hanoi, Vietnam, and \\ Susie S. Cox \\ The University of Louisiana Monroe, Monroe, Louisiana, USA
}

\begin{abstract}
Purpose - This paper employs the theoretical foundations for subjective well-being to examine the impacts of two underlying dimensions of subjective well-being (psychological well-being and social well-being) on proenvironmental consumption behaviors (PECBs). In this research, the moderating role of exposure to positive environmental messages on media in the relationship between subjective well-being and PECBs is also examined.

Design/methodology/approach - This research uses a quantitative research method with data collected from an online survey questionnaire posted in Facebook groups related to PECBs in Vietnam.

Findings - Psychological well-being and social well-being are found to be separate significant predictors of PECBs. More importantly, exposure to positive environmental messages on media was found to reinforce the impacts of psychological well-being on PECB but not moderate the relationship between social well-being and PECB.

Originality/value - This research offers a new insight for encouraging PECB from the perspective of subjective well-being. Different from the extant perspectives, which usually examine subjective well-being as a unidimensional antecedent of PECB, the authors highlight that subjective well-being can influence PECB in two separate dimensions. Moreover, this research extends existing literature by accentuating the role of exposure to environmental messages in the association between different types of social well-being and PECB.
\end{abstract}

Keywords Pro-environmental consumption behavior, Psychological well-being, Social well-being,

Media exposure

Paper type Research paper

\section{Introduction}

Proenvironmental consumption behaviors (PECBs) are normally referred to as prosocial behaviors, which benefit others and promote the benefit of other people and the environment (Schmitt et al., 2018; Zelenski and Desrochers, 2021). Furthermore, PECBs can be potential solutions to reduce environmental damages (Lee and Pounders, 2019; Quoquab et al., 2019; Pham et al., 2021). Recently, an emerging school of thought has argued that if individuals are not happy first, they are not ready to care for other people or the whole society. For example, in a recent study, it is found that only happy people, or those who have high levels of subjective well-being (SWB), are motivated to participate in certain behaviors that can benefit both themselves and the society (Diener et al., 2018). On the contrary, those with lower levels of SWB are more likely to be consumed by their personal worries and concerns and thus, are less likely to participate in societal issues. Similarly, SCORAI Europe (2013) argues that unhappy people are forced to live a modest life, which is more a necessity than a conscious choice and green attitude.

(C) Hung Vu Nguyen, Mai Thi Thu Le, Chuong Hong Pham and Susie S. Cox. Published in Journal of Economics and Development. Published by Emerald Publishing Limited. This article is published under the Creative Commons Attribution (CC BY 4.0) licence. Anyone may reproduce, distribute, translate and create derivative works of this article (for both commercial and non-commercial purposes), subject to full attribution to the original publication and authors. The full terms of this licence may be seen at http:// creativecommons.org/licences/by/4.0/legalcode.

\section{Pro-environ mental consumption behaviors}

Received 22 July 2021 Revised 8 November 2021 Accepted 23 December 2021 
In response to mounting calls for research to determine whether increasing people's pleasant mood or happiness will increase the likelihood to engaging in PECB (Kasser, 2017; Lange and Dewitte, 2020), extant research has shown two main research gaps. First of all, the majority of studies have merely proposed SWB to be antecedent of PECB while considering SWB as a unidimensional construct. However, SWB can fulfill its positive functioning through two underlying dimensions of psychological well-being (PWB) and social well-being (Diener, 1984; Ryff and Keyes, 1995; Prati et al., 2017). Thus, this study would address this first research gap by testing whether each dimension of SWB, PWB and social well-being, can be associated with PECB or not.

Second, existing studies also have encountered inconclusive findings. On the one hand, a happy life is reported to be consistent with a more ecologically sustainable life. Examples for this include giving environmentally friendly gifts or using organic or locally grown foods (Kasser and Sheldon, 2002), purchase of environmentally friendly household products (Welsch and Kuhling, 2010), conservation behaviors (Prati et al., 2017) or buying recycled paper products or shopping with reusable bags is empirically supported (Wang and Kang, 2019; Binder and Blankerberg, 2017). On the other hand, results of a recent experimental research under controlled laboratory conditions did not see sufficient support for a positive association between positive affect, happiness and life satisfaction with PECB (Lange and Dewitte, 2020). Scholars noted that happy people might be too mentally happy to care enough about important contemporary issues, thereby being less likely to act prosocially to improve the society or the world (Kushlev et al., 2020). This means that higher levels of SWB are not always effective predictors of PECB. This therefore leaves room for our present research to conduct further investigation into conditions in which the impact of SWB on PECB can be reinforced. Therefore, this study would aim at filling this second research gap by examining what factor may play the moderating role in the relationship between each underlying dimension of SWB and PECB.

In the field of PECB, exposure to environmental messages on mass media has been reported to have inconclusive findings regarding the direct and indirect impacts on PECB. On the one hand, exposure to environmental messages on mass media has been indicated to positively influence proenvironmental behaviors (Ho et al., 2015; Holbert et al., 2003). When being exposed to messages on mass media, individuals are more aware of their capacity of reducing damage to the environment through their own and other people's consumption behaviors (Han and Xu, 2020). Getting frequently exposed to mass media, individuals are provided with numerous options of PECB, which can help them change their behaviors for the sake of the environment (Hardeman et al., 2017; Simeone and Scarpato, 2020). On the other hand, Liu and Li (2021) have found that exposure to environmental messages on mass media is negatively associated with environmental concern, which will not produce a direct effect on PECB intention and actual behavior. Likewise, Han and Xu (2020) have reported that exposure to messages on tradition media has almost no effect on prenvironmental behavior. As a result, inconsistency among these findings of existing literature has indicated that there should be more examination into the role of exposure to environment messages on mass media in the relationship with PECB. Thus, in this paper, we propose that the frequency of exposure to environmental messages on media may interact with high levels of SWB to reinforce the impacts of SWB on PECB, which is still silent in existing literature.

From the above reasonings, this study aims at addressing two research gaps by employing the SWB theory to test whether PWB and social well-being can positively influence PECB separately or not and whether exposure to environmental messages on mass media can play the moderating role in these relationships.

The rest of this study will be organized as follows. First, we provide our theoretical framework, which includes a model that explains how separate dimensions of SWB influence PECB and the factor that may facilitate or impede the relationship between different types of SWB and PECB. The next section will describe the research methodology, including data 
collection and measurement scales adopted. Hypothesis testing results are shown in the next section. The article finishes with a discussion of the study's findings, limitations as well as suggestions for further research.

\section{Theoretical framework and hypothesis development}

\subsection{Proenvironmental consumption behavior}

PECBs can be referred to as different terms including environmentally responsible behaviors such as green consumption (Peattie, 2010), sustainable consumption (Cohen, 2001), environmentally significant consumption (Stern, 2000), mindful consumption (Sheth et al., 2011). In general, these behaviors generally minimize damages to the environment (Steg and Vlek, 2009). Examples of PECB can include purchasing an energy-efficient household appliances (a hybrid car, an energy-efficient air conditioner), installing to a renewable energy supplier (Lavelle et al., 2015), buying organic food, avoiding heavily packaged products, recycling food containers or avoiding single-use plastic products (Lavelle et al., 2015; Casaló et al., 2019).

Existing literature has commonly suggested that individuals are likely encouraged to conduct PECBs by some influential factors. Some individual factors that may influence PECB include knowledge and education, personality and self-construal, sense of control, values while social factors consist of social norms, social class and culture (Gifford and Nilsson, 2014). Besides, consumers are inclined to conduct PECB when they are provided with necessary facilitating conditions such as green product availability and perceived consumer effectiveness (Nguyen et al., 2019; Lin and Huang, 2012); reasonable price or monetary incentives (Lin and Huang, 2012; Biswas and Roy, 2015). Additionally, a growing number of studies have pointed out that when given substantial information about green products or behaviors (Burke et al., 2014) or point-of-sale information related to proenvironmental products (Frank and Brock, 2018), consumers are more likely to internalize environmental messages and make green choices, accordingly.

\subsection{Subjective well-being}

Since ancient times, individuals, local communities, subcultures and nations have all been interested in pursuing happiness, life satisfaction or well-being. Therefore, the issue related to well-being has sparked a lot of discussion throughout history. Being a commonly accepted concept, well-being is a multifaceted notion encompassing different dimensions of human functioning (McGillivray, 2007). Well-being is arguably best defined by Beddington et al. (2008) to be a state in which an individual can reach their full potential, work productively and creatively, form strong and positive interpersonal relationships and contribute to their community.

While well-being can be categorized differently, researchers seem to agree that it would be more feasible to evaluate subjective well-being. In fact, SWB refers to the individuals' selfreported evaluation of their own well-being (Diener, 1984). Accordingly, SWB denotes people's own evaluations and appraisals of their own lives, including cognitive judgments and emotional responses to ongoing life (Diener et al., 2018; Martín-María et al., 2017). Accordingly, SWB is supposed to involve positive functioning in terms of two underlying dimensions of psychological and social well-being. First, PWB, also referred to as eudaimonic well-being, is achieved through self-acceptance, autonomy, environmental mastery, purpose in life and personal growth (Diener, 1984; Ryff and Keyes, 1995). Second, social well-being is primarily concerned about individuals' perceptions of their relationships with others in the surrounding environment (Prati et al., 2017; Ryff and Keyes, 1995).

Recent research tendency has turned to understand the impacts of SWB on people's life in a wide variety of life domains. Evidently, a large body of existing literature has documented

\section{Pro-environ mental consumption behaviors}


numerous benefits of SWB on both individuals and the society. Generally, people with higher levels of SWB are found to be motivated to participate in certain behaviors or activities (Diener $e t$ al., 2018). More specifically, most research agrees that people with higher levels of SWB tend to lead a healthier life (Pressman and Cohen, 2005) or live longer (Diener and Chan, 2011). Empirical evidence also supports the view that higher levels of SWB tend to make individuals more sociable, have more supportive relationships with surrounding people in their communities and work more productively (De Neve et al., 2013). Besides, it has also been shown by other research findings that happy people are more likely to care for others or for the community and therefore, tend to participate in doing actions that are beneficial for the society, such as doing charity or volunteering (Lyubomirsky et al., 2005; Oishi et al., 2007). It is logical then to link SWB to PECB, which is an individual choice for the sake of not only the consumers but also for other people in the society and for the environment as well (Steg and Vlek, 2009).

As mentioned above, SWB comprises emotional well-being and positive functioning (Diener, 1984; Ryff and Keyes, 1995), in this research, we choose to examine how each underlying dimension of SWB, PWB or social well-being, influences PECB separately.

\subsection{Psychological well-being and proenvironmental consumption behaviors}

PWB is concerned with eudaimonic well-being, which is defined as the achievement of one's full potential and living a meaningful life (Chen et al., 2013). With a high level of PWB, individuals tend to positively evaluate their own capacity to manage their life and surrounding world effectively, pursue a purposeful and meaningful goals in life, grow and develop as a person and develop a sense of autonomy in what they do (Ryff and Keyes, 1995; Ryff and Singer, 2008; Ryff, 1989). In this paper, we argue that PWB may result in PECB. This is because having higher levels of eudaimonic well-being (i.e. PWB), individuals are more likely to make investment in terms of time and effort to set and pursue more intrinsic and nonmaterialistic goals such as environmental protection (Prati et al., 2017). Normally, individuals tend to engage in their behavior through goal setting (DuBrin, 2012; Consolvo et al., 2009). Individuals' attention is guided toward goal-related activities as a result of goal setting, which generates obligations and intentions to achieve a goal or desired behavior (Miner, 2005). When it comes to PECB, existing literature has witnessed goal setting as an effective strategy in encouraging proenvironmental behavior. To put it in another way, when people perceive themselves to be happy, they will make efforts to pursue meaning in life and contribute to the society by conducting PECB. A meta-analysis into factors that can promote proenvironmental behaviors has confirmed that goal setting is among one of the most effective interventions to encourage proenvironmental behaviors (Osbaldiston and Schott, 2011). Therefore, compared to individuals with lower levels of PWB, those with higher levels of PWB tend to set such nonmaterialistic goals, which are beyond their personal fulfillment and find it easier to pursue these goals and satisfy their purpose in life.

Empirically, goal setting is one of influential factors leading to a reduction in electricity consumption (Abrahamse et al., 2005). More recently, findings of a study state that setting goals will increase proenvironmental behaviors such as reducing the use of disposable dishes, carrying a water bottle when away from home instead of using single-use plastic ones (Staples et al., 2020).

Additionally, the guiding role of PWB for sustainable behaviors has also been supported by previous studies. For example, happy people who set clear goals and pursue a meaning in life are more inclined to conduct behaviors that do less harm to the environment such as lower ecological footprint or less frequent car use (Csutora and Zsóka, 2012). Besides, research has found that individuals, whose needs for personal growth, self-acceptance or their intrinsic life goals are satisfied, are more inclined to engage in environmentally friendly behavior such as cycling or recycling (Kasser and Sheldon, 2002). Furthermore, Ganglmair-Wooliscroft and 
Wooliscroft (2019) have also reported eudaimonic well-being to have a positive correlation with everyday ethical consumption behaviors such as recycling or buying local products.

For the above arguments and empirical evidence, we formally hypothesize:

H1. PWB will be positively associated with PECB.

\section{Pro-environ mental consumption behaviors}

\subsection{Social well-being and PECB}

Theoretically, social well-being refers to how individuals perceive their relationships with others in the surrounding environment (Ryff and Keyes, 1995; Prati et al., 2017) and how individuals thrive in their own public, social life (Keyes, 2002, 2003). As such, social well-being is proposed to be an important predictor of proenvironmental behavior because it refers to the sense of belonging to the community, doing things that are beneficial for others and for the society (Prati et al., 2017). Kasser (2017) also supports the view that people with high levels of social well-being tend to have high prosocial orientation.

Therefore, evidence for the relationship between social well-being and PECB, thus, can be found in prosocial behavior-related research. With regard to the PECB literature, doing things for the benefits of others and for the benefit of the ecosystem is proposed to result in proenvironmental behavior (De Groot and Steg, 2009). More specifically, PECB is empirically proved to be promoted by prosocial motivation because prosocially motivated people tend to satisfy their innate psychological need to connect with and care for other members in the society (Pham et al., 2021). Empirically, it has been found that social well-being can lead to participation in prosocial behaviors, which are related to PECB such as environmentally responsible clothing (Reimeirs et al., 2017), energy conservation (Prati et al., 2017), paying high prices for environmentally friendly products or refusing to use products that are potentially harmful for the environment (Wang and Kang, 2019). For the above arguments and evidence, we can expect social well-being would influence PECB. Therefore, we hypothesize that:

\section{H2. Social well-being will be positively associated with PECB.}

\subsection{The moderating effects in the relationship between subjective well-being and PECB}

When it comes to environmental messages, the diffusion of negative messages about environmental damages on media channels has been reported to discourage people's participation in green behaviors (Li et al., 2018). In contrast, information about green behaviors such as energy saving or other proenvironmental consumption alternatives spread through media channels, including social network, is confirmed to attract more proenvironmental behaviors (Li et al., 2019; Tong et al., 2020). This research focuses on positive messages or information about green behaviors, green alternatives or choice of PECB that are communicated and spread on different types of media such as TV, newspapers, the Internet and social networking sites. In this paper, we propose that the frequency of exposure to positive environmental messages on media to be one such condition, which can encourage PECB among people with high levels of SWB.

Firstly, people with high PWB tend to positively assess their own ability to manage life effectively, be able to set a purpose in their life, grow and develop as a person and develop a sense of autonomy. They will make efforts to pursue meaning in life and contribute to the society by conducting PECB (Prati et al., 2017). When these people are exposed to positive environmental messages on mass media, they are more likely to conduct PECB. The first reason is that media is a vital source of environmental information, which can increase individuals' awareness of benefits of PECB and recommend alternatives of PECB (Olausson, 2011; Nisbet, 2009). When individuals are frequently exposed to positive environmental messages about "green choices" on media channels, they are more confident in evaluating their ability to pursue a purposeful goal in their life (Arlt et al., 2011; Östman, 2014). Second, being more frequently exposed to messages 
about green behaviors on different media channels, they can be provided with sustainable tourism choices (Hardeman et al., 2017) or environmentally friendly consumer food choices (Simeone and Scarpato, 2020). Thanks to this, they can establish a certain level of autonomy and can more easily choose relevant behaviors to help them attain their goals, thereby enhancing their level of PWB. From those reasonings, frequent exposure to environmental messages on mass media has activated psychological social well-being, which will inherently promote PECB. Therefore, exposure to positive environmental messages on mass media can reinforce the impacts that PWB has on PECB.

Hence, the following hypothesis is posited:

H3. The positive association between PWB and PECB is strengthened by exposure to environmental messages on media channels.

Secondly, we argue that individuals who have both high levels of social well-being and high frequency of exposing to environmental messages on mass media channels would be more likely to perform PECB. First, as previously discussed, individuals with high levels of social well-being tend to pay attention to information related to and/or from others in their social community in light of benefits for others (Keyes, 1998). They are more likely to perceive that their PECB is valued by the society and can contribute to the common good of the whole society. Hence, the perception of having a strong relationship with other people in their community can enhance their level of social well-being, thereby motivating them to conduct more PECB. Second, people with high levels of social well-being are likely to have prosocial orientations (Feng and Zhang, 2021) and are motivated to conduct PECB for the welfare of other people of the natural environment (Wang and Kang, 2019). When these people are frequently exposed to positive environmental messages on mass media channels, they will become aware of tips, best practices and suggestions of proenvironmental alternatives of consumption behaviors, which are usually referred to as a prosocial message (Rushton, 1982). Repeated exposure to prosocial media may even further enhance prosocial motivation (Neubaum et al., 2020), which will evidently activate a higher level of social well-being. Concluding from those arguments, high frequency of exposure to environmental messages on media channels would be associated with a stronger impact of social well-being on PECB. Therefore, we hypothesize that:

H4. The positive association between social well-being and PECB is strengthened by exposure to environmental messages on media channels.

The study framework is demonstrated in Figure 1 below.

\section{Research methodology}

\subsection{Participants}

Participants of this research were adults living in Vietnam, aged from 18 to over 55. The research survey questionnaires were distributed electronically to members of a wide variety of green communities or proenvironmental communities. These communities are online based in Facebook groups among Vietnamese members. These groups normally share green ideas or practices or examples of daily PECB to each other such as how to reduce single-use plastics, where to buy organic food, tips of electricity and water conservation, recycling ideas and so on. The survey questionnaires were posted on these communities in one week in October 2020, and 378 valid responses were collected for further analysis to test the proposed relationships in the theoretical framework.

\subsection{Measures}

Measures of SWB (both psychological well-being and social well-being) were adapted from the study of Pontin et al. (2013). Exposure to environmental messages on media was measured 


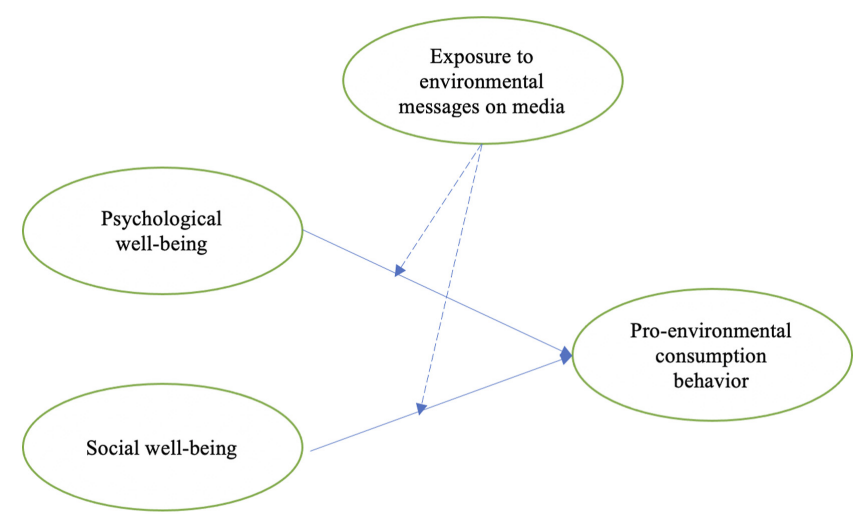

Pro-environ mental consumption behaviors

Figure 1. Theoretical framework

based on the measurement scales adapted from Lee (2010) regarding the frequency of getting exposure to environmental messages on TV, newspapers, the Internet and social networking sites. With the Facebook group respondents, the messages received are usually about environmental-friendly behaviors or campaigns carried out in societies. Finally, PECB was assessed by modifying the measurement scales of Taufique et al. (2014), which were about environmentally responsible consumer behaviors. All variables were measured using the multi-item Likert-type scales from 1 as Strongly Disagree to 5 as Strongly Agree.

\section{Results and discussion}

\subsection{Sample profile}

The profile of the sample reveals that $59.3 \%$ were females compared to $40.7 \%$ of males; $52.9 \%$ of the participants were between 18 and 45 years old while $32.5 \%$ of them were from 46 to 55 years old; And $14.6 \%$ of the participants were over 55 years old.

\subsection{Reliability and validity analysis}

Two statistical tools of SPSS 20.0 and AMOS 20.0 were used to test reliability, validity and discriminant validity of the scales. All scales, except for the measurement scale of exposure to environmental messages on media - a formative scale, were subject to exploratory and confirmatory factor analysis. Exploratory factor analysis (EFA) suggested that these measurement scales (PWB, social well-being, PECB) had a unidimensional structure. Cronbach's $\alpha$ for these constructs variables were all above 0.8 , ranging from 0.846 to 0.911 , which indicates good internal consistency (see Table 1).

To assess the convergent validity of all constructs, the average variance extracted (AVE) scores were computed. Factor loadings of these constructs are all higher than 0.5 while all AVE scores were greater than 0.50, demonstrating acceptable convergent validity (Hair et al., 2018). Additionally, the AVE score for each construct was greater than its correlation with the other constructs, demonstrating discriminant validities of the measures (Fornell and Larcker, 1981) (see Table 1).

\subsection{Hypothesis testing}

The statistical tool of WarpPLS 7.0 was applied to test the hypothesized relationships. Two control variables of Gender and Age were also included in the model. Table 2 presents a summary of the hypothesis testing results. 
JED

\begin{tabular}{|c|c|c|c|c|c|}
\hline Measurements & & $\begin{array}{l}\text { Internal } \\
\text { consistency }\end{array}$ & 1 & $\begin{array}{c}\text { Validity } \\
2\end{array}$ & 3 \\
\hline $\begin{array}{l}\text { 1. Psychological } \\
\text { well-being }\end{array}$ & $\begin{array}{l}\text { Do you feel able to enjoy life? } \\
\text { Do you feel you have a purpose in life? } \\
\text { Do you feel in control of your life? } \\
\text { Do you feel able to live your life the way you } \\
\text { want? } \\
\text { Are you confident in your own opinions and } \\
\text { beliefs? } \\
\text { Do you feel able to do the things you choose } \\
\text { to do? } \\
\text { Do you feel able to grow and develop as a } \\
\text { person? }\end{array}$ & 0.901 & 0.585 & & \\
\hline $\begin{array}{l}\text { 2. Social well- } \\
\text { being }\end{array}$ & $\begin{array}{l}\text { Are you happy with your friendships and } \\
\text { personal relationships? } \\
\text { Are you comfortable about the way you } \\
\text { relate and connect with others? } \\
\text { Are you able to ask someone for help with a } \\
\text { problem? }\end{array}$ & 0.846 & 0.084 & 0.660 & \\
\hline 3. PECB & $\begin{array}{l}\text { Whenever it is possible, I do not buy } \\
\text { products with plastic wrapping } \\
\text { I often shop at stores that promote "reduce } \\
\text { single use plastic" products } \\
\text { I often bring my own containers/bottles } \\
\text { when I eat or drink out } \\
\text { I buy products that are friendly for the } \\
\text { environment whenever possible } \\
\text { I try to be pro-environmental by shopping at } \\
\text { places that are known to be } \\
\text { environmentally friendly } \\
\text { I shop or eat out at stores or restaurants } \\
\text { which emphasize environmental protection } \\
\text { whenever possible } \\
\text { Whenever possible, I buy products that are } \\
\text { packaged in recyclable materials }\end{array}$ & 0.911 & 0.557 & 0.257 & 0.602 \\
\hline
\end{tabular}

Reliability and validity of the measurement

Note(s): Numbers in the diagonal and italices are AVEs. Others that are italicized are correlations squared scales between variables

Table 2.

Moderating effect of exposure to environmental messages on media

\begin{tabular}{lcccccc}
\hline & $\begin{array}{c}\text { Path } \\
\text { coefficient } \\
(\beta)\end{array}$ & $\begin{array}{c}\text { Average } \\
\text { adjusted } \\
\text { Path }\end{array}$ & $\begin{array}{c}\text { Average } \\
R \text {-squared }\end{array}$ & $\begin{array}{c}\text { Average full } \\
\text { collinearity } \\
\text { block VIF }\end{array}$ & VIF & Supported? \\
\hline Gender & -0.006 & 0.453 & 0.584 & 1.259 & 1.457 & No \\
Age & $0.12 * *$ & 0.009 & $(p<0.001)$ & & & Yes \\
H1: PWB $\rightarrow$ PECB & $0.505 * * *$ & 0.000 & & & & Yes \\
H2: SoWB $\rightarrow$ PECB & $0.291 * * *$ & 0.000 & & & Yes \\
H3: PWB*MediaExp $\rightarrow$ PECB & $0.143^{* * *}$ & 0.002 & & & Yes \\
H4: SoWB*MediaExp $\rightarrow$ PECB & 0.023 & 0.327 & & No \\
Note(s): Significant at confidence levels of $* 95 \% ; * * 99 \% ; * * * 99.9 \% ; N=378$ & & \\
\hline
\end{tabular}

As can be seen from Table 2, both Average Block VIF and the Average Full Collinearity VIF are smaller than the cutoff value of 3.33, demonstrating no collinearity problem. Independent variables in the model explained $59 \%$ of the variance in PECB variable. The estimates for the 
direct relationship between PWB and social well-being and PECB were 0.505 and 0.291 , respectively with $p$ values lower than 0.001 . $\mathrm{H} 1$ and $\mathrm{H} 2$ then are supported.

In testing for moderation, the interaction term between PWB and exposure to environmental messages on media has a significant positive impact on PECB. Thus exposure to environmental messages has a positive complete moderating effect on the relationship between PWB and PECB. H3 then is supported.

However, the interaction term between social well-being and exposure to environmental messages on media is positive but not significant. H4 then is not supported.

\section{Discussion}

\subsection{Theoretical implication}

Overall, our findings confirm that besides the effects of general SWB on the engagement in PECB indicated by existing literature, each underlying dimension of SWB, PWB or social well-being also has a separate positive relationship with PECB. This is consistent with explanation for the positive association between these two dimensions and PECB (Lyubomirsky et al., 2005). First, it is found in our research that the significant impact that PWB has on PECB corroborates with previous studies about the important role pursing a meaningful purpose in life plays in promoting general behaviors (DuBrin, 2012; Consolvo et al., 2009) and proenvironmental behaviors (Osbaldiston and Schott, 2011; Staples et al., 2020). Second, our research indicates that people with higher levels of social well-being tend to participate in PECB because they are more concerned about their relationships with others in the community. This is also in line with arguments and empirical evidence from previous studies (Reimeirs et al., 2017; Prati et al., 2017). Furthermore, our findings found that exposure to positive environmental behavior messages on media channels facilitates the impact of PWB on PECB. With frequent exposure to environmental messages on mass media, individuals are more capable of satisfying their need for self-acceptance, self-autonomy and effective development and growth as a person in life. As a result, the impacts of PWB on PECB are further strengthened.

However, contrary to what was hypothesized, exposure to environmental messages on media channels is not found to moderate the relationship between social well-being and PECB. Explanations for this may originate from contrasting points of view among people with high levels of social well-being. One possible reason for this may be the "Bystander Effect" (Latane and Darly, 1970). This is a concept from the lens of social psychology, explaining why people are reluctant or less likely to help someone in a needed situation if there are other people around. There are four major components of the bystander effect, namely self-awareness, social cues, blocking mechanisms and distributed responsibility. The concept of bystander effect can be used to explain situations related to social media exposure and proenvironmental behaviors as well. That is, when these people are frequently exposed to environmental messages on media, they tend to believe that there are many other people who have already conducted or will be conducting PECB for the welfare of the environment. Accordingly, they may sometimes relax themselves and do not suppress their personal interest for some occasional consumption behaviors that are not environmentally friendly. This further corroborates with the view that a helping behavior such as a proenvironmental behavior is sometimes less likely to occur when people recognize others who will potentially conduct the desired behavior (Granzin and Olson, 1991).

\subsection{Practical implications}

The current study also offers some practical implications to encourage more participation in PECBs in people's daily lives. As indicated from the research findings, those who are 
typically happy with their life tend to participate more in PECB. Accordingly, policymakers should consider policies that can directly improve levels of well-being among citizens. In order to do so, governmental agencies should develop programs to evaluate what are the indicators of life satisfaction of citizens. Based on that, specific measures can be taken to decrease depression and anxiety levels and increase satisfaction levels of citizens.

Second, for citizens who choose to lead a sustainable lifestyle, communication campaigns to promote more PECB should provide viewers with positive emotions, such as being cheerful, hopeful or motivational instead of providing negative ones such as guilt, anger, disappointment or threats. Besides, intervention campaigns should also emphasize that those behaviors are not only beneficial for other people in the society, beneficial for the environment but also beneficial for themselves because they can make them feel an inner happiness because of being able to set and achieve meaningful purposes in life. More importantly, these behaviors could be a chance for them to benefit from psychological gains from being a member of a righteous community. Being a member in such a community, they can be happy with relationships with each other, feel a sense of belonging to the community and experience community participation at the same time.

\subsection{Limitation and further research}

This research is not without limitation. Firstly, the data for the study were collected from members of Facebook groups who focus on green consumption and proenvironmental activities in Vietnam. These groups often publish posts about ideas, recommendations or tips about alternatives that are environmentally friendly so that other members can follow such green practices to be beneficial for the nature. When they are asked about the frequency of their exposure to general environmental messages, it is evidently implied that these messages are suggested ideas about daily PECB. Therefore findings may be not generalized for those who may not belong to these groups. Future research, however, may look into the impacts of exposure to other different types of environmental information on the relationship between different dimensions of SWB and PECB and among other general samples. Second, the selfreported PECB used in this research may not exactly assess the participants' actual pattern of behaviors. Although respondents were asked to recall their actual participation in PECB in their daily life activities, responses may not be considered as actual behaviors. Future research would benefit from the examination of another research design such as longitudinal experiments.

\subsection{Conclusion and future research direction}

To wrap up, our study findings first contribute to existing well-being literature by indicating that SWB can separately influence PECB in two separate dimensions: PWB and social well-being. Second, our results also extend a larger body of literature on prosocial media effects (Li et al., 2018, 2019; Neubaum et al., 2020). In fact, our study confirms the different roles that exposure to positive environmental messages on media play in the relationship between different dimensions of SWB and proenvironmental consumption behavior.

Future research then may look into the impacts of exposure to other different types of environmental information on the relationship between different dimensions of SWB and PECB and among other general samples. Second, to tackle the limitation of using a self-reported measurement scale for PECB, future research would benefit from the examination of another research design such as longitudinal experiments.

\section{References}

Abrahamse, W., Steg, L., Vlek, C. and Rothengatter, T. (2005), “A review of intervention studies aimed at household energy conservation”, Journal of Environmental Psychology, Vol. 25, pp. 273-291. 
Arlt, D., Hoppe, I. and Wolling, J. (2011), "Climate change and media usage: effects on problem awareness and behavioural intentions", International Communication Gazette, Vol. 73 Nos 1-2, pp. 45-63.

Beddington, J., Cooper, C.L., Field, J., Goswami, U., Huppert, F.A., Jenkins, J., Jones, H.S., Kirkwood, T.B.L., Sahakian, B.J. and Thomas, S.M. (2008), "The mental wealth of nations", Nature, Vol. 455, pp. 1057-1060.

Binder, M. and Blankenberg, A.K. (2017), "Green lifestyles and subjective well-being: more about selfimage than actual behavior?", Journal of Economic Behavior and Organization, Vol. 137, pp. 304-323.

Biswas, A. and Roy, M. (2015), "Leveraging factors for sustained green consumption behavior based on consumption value perceptions: testing the structural model", Journal of Cleaner Production, Vol. 95, pp. 332-340.

Burke, P.F., Eckert, C. and Davis, S. (2014), "Segmenting consumers' reasons for and against ethical consumption”, European Journal of Marketing, Vol. 48 Nos 11-12, pp. 2237-2261.

Casaló, L.V., Escario, J.J. and Rodriguez-Sanchez, C. (2019), "Analyzing differences between different types of pro-environmental behaviors: do attitude intensity and type of knowledge matter?", Resources, Conservation and Recycling, Vol. 149, pp. 56-64.

Chen, F.F., Jing, Y., Hayes, A. and Lee, J.M. (2013), "Two concepts or two approaches? A bifactor analysis of psychological and subjective well-being", Journal of Happiness Studies, Vol. 14 No. 3, pp. 1033-1068.

Cohen, M. (2001), "The emergent environmental policy discourse on sustainable consumption", in Cohen, M. and Murphy, J. (Eds), Exploring Sustainable Consumption: Environmental Policy and the Social Sciences, Elsevier, New York, pp. 21-37.

Consolvo, S., McDonald, D.W. and Landay, J.A. (2009), Theory-driven Design Strategies for Technologies that Support Behavior Change in Everyday Life, Proceedings of the SIGCHI Conference on Human Factors in Computing Systems, ACM.

Csutora, M. and Zsóka, Á. (2012), "Relation of spirituality to happiness, life satisfaction and sustainable lifestyles", Spirituality and Sustainability: A New Path for Entrepreneurship, pp. 1-33.

De Groot, J.I.M. and Steg, L. (2009), "Mean or green: which values can promote stable proenvironmental behavior?", Conservation Letters, Vol. 2 No. 2, pp. 61-66.

De Neve, J.E., Diener, E., Tay, L. and Xuereb, C. (2013), "The objective benefits of subjective wellbeing", World Happiness Report.

Diener, E. (1984), “Subjective well-being”, Psychological Bulletin, Vol. 95, pp. 542-575.

Diener, E. and Chan, M.Y. (2011), "Happy people live longer: subjective well-being contributes to health and longevity", Applied Psychology: Health and Well-Being, Vol. 3 No. 1, pp. 1-43.

Diener, E., Oishi, S. and Tay, L. (2018), “Advances in subjective well-being research”, Nature Human Behaviour, Vol. 2 No. 4, pp. 253-260.

DuBrin, A.J. (2012), Essentials of Management, Cengage South-Western, Mason, OH.

Feng, L. and Zhang, L. (2021), "Prosocial tendencies and subjective well-being: the mediating role of basic psychological needs satisfaction", Social Behavior and Personality: An International Journal, Vol. 49 No. 5, pp. 1-10.

Fornell, C. and Larcker, D.F. (1981), "Evaluating structural equation models with unobservable variables and measurement error", Journal of Marketing Research, Vol. 18 No. 1, pp. 39-50.

Frank, P. and Brock, C. (2018), "Bridging the intention-behavior gap among organic grocery customers: the crucial role of point-of-sale information”, Psychology and Marketing, Vol. 35 No. 8, pp. 586-602.

Ganglmair-Wooliscroft, A. and Wooliscroft, B. (2019), "Well-being and everyday ethical consumption”, Journal of Happiness Studies, Vol. 20 No. 1, pp. 141-163.

Gifford, R. and Nilsson, A. (2014), "Personal and social factors that influence pro-environmental concern and behaviour: a review”, International Journal of Psychology, Vol. 49 No. 3, pp. 141-157.
Pro-environ mental consumption behaviors

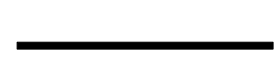


Granzin, K.L. and Olson, J.E. (1991), "Characterizing participants in activities protecting the environment: a focus on donating, recycling, and conservation behaviors", Journal of Public Policy and Marketing, Vol. 10 No. 2, pp. 1-27.

Hair, J.F., Black, W.C., Babin, B.J. and Anderson, R.E. (2018), Multivariate Data Analysis, 8th ed., Cengage, London.

Han, R. and Xu, J. (2020), "A comparative study of the role of interpersonal communication, traditional media and social media in pro-environmental behavior: a China-based study", International Journal of Environmental Research and Public Health, Vol. 17 No. 6, p. 1883.

Hardeman, G., Font, X. and Nawijn, J. (2017), "The power of persuasive communication to influence sustainable holiday choices: appealing to self-benefits and norms", Tourism Management, Vol. 59, pp. 484-493.

Ho, S.S., Liao, Y. and Rosenthal, S. (2015), "Applying the theory of planned behavior and media dependency theory: predictors of public pro-environmental behavioral intentions in Singapore", Environmental Communication, Vol. 9 No. 1, pp. 77-99, doi: 10.1080/17524032.2014.932819.

Holbert, R.L., Kwak, N. and Shah, D.V. (2003), "Environmental concern, patterns of television viewing, and pro-environmental behaviors: integrating models of media consumption and effects", Journal of Broadcasting and Electronic Media, Vol. 47 No. 2, pp. 177-196, doi: 10.1207/ s15506878jobem4702_2.

Kasser, T. (2017), "Living both well and sustainably: a review of the literature, with some reflections on future research, interventions and policy", Philosophical Transactions of the Royal Society A: Mathematical, Physical and Engineering Sciences, Vol. 375, p. 20160369.

Kasser, T. and Sheldon, K.M. (2002), "What makes for a merry Christmas?", Journal of Happiness Studies, Vol. 3 No. 4, pp. 313-329.

Keyes, C.L.M. (1998), "Social well-being”, Social Psychology Quarterly, Vol. 61, pp. 121-140.

Keyes, C.L.M. (2002), "The mental health continuum: from languishing to flourishing in life", Journal of Health and Social Behavior, Vol. 43 No. 2, pp. 207-222, doi: 10.2307/3090197.

Keyes, C.L.M. (2003), "Complete mental health: an agenda for the 21st century", in Keyes, C.L.M. and Haidt, J. (Eds), Flourishing: Positive Psychology and the Life Well-Lived, American Psychological Association, Washington, DC, pp. 293-312, doi: 10.1037/10594-013.

Kushlev, K., Drummond, D.M., Heintzelman, S.J. and Diener, E. (2020), "Do happy people care about society's problems?", The Journal of Positive Psychology, Vol. 15 No. 4, pp. 467-477.

Lange, F. and Dewitte, S. (2020), "Positive affect and pro-environmental behavior: a preregistered experiment", Journal of Economic Psychology, Vol. 80, p. 102291.

Latane, B. and Darley, J.M. (1970), The Unresponsive Bystander: Why Doesn't He Help?, AppletonCentury-Crofts, New York, NY.

Lavelle, M.J., Rau, H. and Fahy, F. (2015), "Different shades of green? Unpacking habitual and occasional pro-environmental behavior", Global Environmental Change, Vol. 35, pp. 368-378.

Lee, K. (2010), "The green purchase behavior of Hong Kong young consumers: the role of peer influence, local environmental involvement, and concrete environmental knowledge", Journal of International Consumer Marketing, Vol. 23 No. 1, pp. 21-44.

Lee, S. and Pounders, K.R. (2019), "Intrinsic versus extrinsic goals: the role of self-construal in understanding consumer response to goal framing in social marketing", Journal of Business Research, Vol. 94, pp. 99-112.

Li, W., Tian, L. and Batool, H. (2018), "Impact of negative information diffusion on green behavior adoption", Resources, Conservation and Recycling, Vol. 136, pp. 337-344.

Li, W., Tian, L., Gao, X. and Pan, B. (2019), "Impacts of information diffusion on green behavior spreading in multiplex networks", Journal of Cleaner Production, Vol. 222, pp. 488-498.

Lin, P.C. and Huang, Y.H. (2012), "The influence factors on choice behavior regarding green products based on the theory of consumption values", Journal of Cleaner Production, Vol.22 No.1, pp.11-18. 
Liu, Y. and Li, X. (2021), "Pro-environmental behavior predicted by media exposure, SNS involvement, and cognitive and normative factors", Environmental Communication, pp. 1-15.

Lyubomirsky, S., King, L. and Diener, E. (2005), "The benefits of frequent positive affect: does happiness lead to success?”, Psychological Bulletin, Vol. 131 No. 6, p. 803.

Martín-María, N., Miret, M., Caballero, F.F., Rico-Uribe, L.A., Steptoe, A., Chatterji, S. and Ayuso-Mateos, J.L. (2017), "The impact of subjective well-being on mortality: a meta-analysis of longitudinal studies in the general population", Psychosomatic Medicine, Vol. 79 No. 5, pp. 565-575.

McGillivray, M. (2007), "Human well-being: issues, concepts and measures", Human Well-Being, Palgrave Macmillan, London, pp. 1-22.

Miner, J.B. (2005), Goal Setting Theory: Essential Theories of Motivation and Leadership Organizational Behaviour, ME Sharpe, Armonk (NY, US).

Neubaum, G., Krämer, N.C. and Alt, K. (2020), "Psychological effects of repeated exposure to elevating entertainment: an experiment over the period of 6 weeks", Psychology of Popular Media, Vol. 9 No. 2, pp. 194-207.

Nguyen, H.V., Nguyen, C.H. and Hoang, T.T.B. (2019), "Green consumption: closing the intentionbehavior gap”, Sustainable Development, Vol. 27 No. 1, pp. 118-129.

Nisbet, M.C. (2009), "Communicating climate change: why frames matter for public engagement", Environment: Science and Policy for Sustainable Development, Vol. 51 No. 2, pp. 12-23.

Oishi, S., Diener, E. and Lucas, R.E. (2007), “The optimum level of well-being: can people be too happy?”, Perspectives on Psychological Science, Vol. 2, pp. 346-360.

Olausson, U. (2011), "We're the ones to blame: citizens' representations of climate change and the role of the media", Environmental Communication: A Journal of Nature and Culture, Vol. 5 No. 3, pp. 281-299.

Osbaldiston, R. and Schott, J.P. (2011), "Environmental sustainability and behavioral science", Environment and Behavior, Vol. 44 No. 2, pp. 257-299.

Östman, J. (2014), "The influence of media use on environmental engagement: a political socialization approach", Environmental Communication, Vol. 8 No. 1, pp. 92-109.

Peattie, K. (2010), "Green consumption: behavior and norms", Annual Review of Environment and Resources, Vol. 35, pp. 195-228.

Pham, C.H., Nguyen, H.V., Le, M.T.T., Do, L.T. and Nguyen, P.T.T. (2021), "The synergistic impact of motivations on sustained pro-environmental consumer behaviors: an empirical evidence for single-use plastic products", Asia Pacific Journal of Marketing and Logistics.

Pontin, E., Schwannauer, M., Tai, S. and Kinderman, P. (2013), "A UK validation of a general measure of subjective well-being: the modified BBC subjective well-being scale (BBC-SWB)", Health and Quality of Life Outcomes, Vol. 11 No. 1, pp. 1-9.

Prati, G., Albanesi, C. and Pietrantoni, L. (2017), "Social well-being and pro-environmental behavior: a cross-lagged panel design", Human Ecology Review, Vol. 23 No. 1, pp. 123-139.

Pressman, S.D. and Cohen, S. (2005), "Does positive affect influence health?”, Psychological Bulletin, Vol. 131 No. 6, p. 925.

Quoquab, F., Mohammad, J. and Sukari, N.N. (2019), “A multiple-item scale for measuring 'sustainable consumption behaviour' construct", Asia Pacific Journal of Marketing and Logistics, Vol. 31 No. 4, pp. 791-816.

Reimers, V., Magnuson, B. and Chao, F. (2017), "Happiness, altruism and the Prius effect: how do they influence consumer attitudes towards environmentally responsible clothing?", Journal of Fashion Marketing and Management: An International Journal, Vol. 21 No. 1, pp. 115-132.

Rushton, J.P. (1982), “Television and prosocial behavior”, in Pearl, D., Bouthilet, 'L. and Lazar, J. (Eds), Television and Behavior: Ten Years of Scientific Progress and Implications for the Eighties, National Institute of Mental Health, Bethesda, MD, Vol. 2, pp. 248-258.

Ryff, C.D. (1989), "Happiness is everything, or is it? Explorations on the meaning of psychological well- being", Journal of Personality and Social Psychology, Vol. 57, pp. 1069-1081.

\section{Pro-environ mental consumption behaviors}


Ryff, C.D. and Keyes, C.L.M. (1995), "The structure of psychological well-being revisited", Journal of Personality and Social Psychology, Vol. 69, pp. 719-727.

Ryff, C.D. and Singer, B.H. (2008), "Know thyself and become what you are: a eudaimonic approach to psychological well-being", Journal of Happiness Studies, Vol. 9, pp. 13-39.

Schmitt, M.T., Aknin, L.B., Axsen, J. and Shwom, R.L. (2018), "Unpacking the relationships between pro-environmental behavior, life satisfaction, and perceived ecological threat", Ecological Economics, Vol. 143, pp. 130-140.

SCORAI Europe (2013), "Bridging across communities and cultures towards sustainable consumption", Sustainable Consumption Transitions Series, No. 3, SCORAI Europe Workshop Proceedings: June 4, 2013, Istanbul, Turkey.

Sheth, J.N., Sethia, N.K. and Srinivas, S. (2011), "Mindful consumption: a customer-centric approach to sustainability", Journal of the Academy of Marketing Science, Vol. 39 No. 1, pp. 21-39.

Simeone, M. and Scarpato, D. (2020), "Sustainable consumption: how does social media affect food choices?”, Journal of Cleaner Production, Vol. 277, p. 124036, doi: 10.1016/j.jclepro.2020.124036.

Staples, S., Webster, J. and Lv, S.C. (2020), "Comparing goal setting approaches to boosting pro-environmental behaviors", Journal of Sustainability Research, Vol. 4, p. 3.

Steg, L. and Vlek, C. (2009), "Encouraging pro-environmental behavior: an integrate review and research", Journal of Environmental Psychology, Vol. 29 No. 3, pp. 309-317.

Stern, P. (2000), "Toward a coherent theory of environmentally significant behavior", Journal of Social Issues, Vol. 56 No. 3, pp. 407-424.

Taufique, K.M.R., Siwar, C.B., Talib, B.A. and Chamhuri, N. (2014), "Measuring consumers' environmental responsibility: a synthesis of constructs and measurement scale items", Current World Environment, Vol. 9 No. 1, p. 27.

Tong, Z., Liu, D., Ma, F. and Xu, X. (2020), "Good news or bad news? How message framing influences consumers' willingness to buy green products", Frontiers in Psychology, Vol. 11.

Wang, E. and Kang, N. (2019), "Does life satisfaction matter for pro-environmental behavior? Empirical evidence from China General Social Survey", Quality and Quantity, Vol. 53, p. 1.

Welsch, H. and Kühling, J. (2010), "Pro-environmental behavior and rational consumer choice: evidence from surveys of life satisfaction”, Journal of Economic Psychology, Vol. 31 No. 3, pp. $405-420$.

Zelenski, J.M. and Desrochers, J.E. (2021), "Can positive and self-transcendent emotions promote pro-environmental behavior?", Current Opinion in Psychology, Vol. 42, pp. 31-35.

\section{Corresponding author}

Mai Thi Thu Le can be contacted at: maile@neu.edu.vn

For instructions on how to order reprints of this article, please visit our website:

www.emeraldgrouppublishing.com/licensing/reprints.htm

Or contact us for further details: permissions@emeraldinsight.com 